\title{
Pengaruh Ekstrak Kasar Umbi Udara Binahong (Anredera cordifolia(Ten.) Steenis) terhadap Penghambatan Koloni dan Kejadian Penyakit Akibat Alternaria solani pada Bibit Tomat
}

\author{
Endah Yulia ${ }^{1}$, Rumenda Tamariska Bangun ${ }^{2}$, Tohidin ${ }^{1}$, dan Hersanti ${ }^{1}$ \\ ${ }^{1}$ Departemen Hama dan Penyakit Tumbuhan, Fakultas Pertanian, Universitas Padjadjaran \\ ${ }^{2}$ Program Studi Agroteknologi, Fakultas Pertanian, Universitas Padjadjaran \\ Jl. Raya Bandung Sumedang KM 21 Jatinangor Jawa Barat 45363 \\ *Alamat korespondensi: endah.yulia@unpad.ac.id
}

\begin{tabular}{lrc}
\hline \multicolumn{2}{l}{ INFO ARTIKEL } & ABSTRACT/ABSTRAK \\
\hline Diterima: & $12-08-2021$ & \\
Direvisi: & $11-10-2021$ & The Effect of Binahong (Anredera cordifolia (Ten.) Steenis) Air Tuber Extract \\
Dipublikasi:23-01-2022 & on Colony Inhibition and Disease Suppression Caused by Alternaria solani in \\
& & Tomato Seedlings
\end{tabular}

Keywords:

Botanical pesticide, Early blight,

Tomato

Kata Kunci:

Bercak cokelat,

Pestisida nabati,

Tomat
Alternaria solani is the causal agent of brown spot (early blight) disease on tomato plants. The fungal infection causes tomato plants to stunt, fall or die. Infection in tomato seedlings can cause damping-off, leaf spot, or seedling rot. The use of botanical pesticides or plant extracts to control diseases in several types of plants has been widely explored. One of the plant species that can be used as a botanical pesticide is binahong (Anredera cordifolia) which being popular used as traditional medicine for health and as an antimicrobial agent. The purpose of this study was to test the ability of crude extract of binahong air tuber in inhibiting the growth of $A$. solani colony and suppressing the incidence of disease in tomato seedlings. The research method used was a completely randomized design (CRD) consisting of seven treatments (extract concentrations of $0.25 \%, 0.5 \%, 1 \%, 2 \%$, and $4 \%$; control without extract; and propineb fungicide $0.3 \%$ ) that replicated four times for fungal colony inhibition test using poisoned food technique. Tests on seeds were carried out with four treatments and five replications, each consisted of 25 tomato seeds using the seed immersion technique. The results showed that $2 \%$ binahong air tuber crude extract inhibited the $A$. solani colony growth with the inhibition percentage of $37.22 \%$ and had ability to suppress the incidence of disease in tomato seedlings with suppression reached up to $83.33 \%$.

Alternaria solani merupakan patogen penyebab penyakit bercak cokelat pada tanaman tomat. A. solani mampu menyerang hampir seluruh bagian tanaman yaitu tangkai, batang, daun, ranting maupun buah tomat. Serangan pada benih dapat menyebabkan benih rebah, bercak atau benih menjadi busuk. Penggunaan pestisida nabati atau ekstrak tanaman untuk mengendalikan penyakit pada beberapa jenis tanaman telah banyak digunakan. Salah satu bahan alam yang dapat digunakan sebagai pestisida nabati ialah tanaman binahong (Anredera cordifolia) yang merupakan tanaman yang populer digunakan sebagai obat tradisional untuk kesehatan maupun sebagai bahan antimikroba. Penelitian ini bertujuan untuk menguji kemampuan ekstrak kasar umbi udara binahong dalam menghambat pertumbuhan koloni jamur $A$. solani serta menekan kejadian penyakit pada bibit tomat. Penelitian menggunakan Rancangan Acak Lengkap (RAL) yang terdiri atas tujuh perlakuan (konsentrasi ekstrak 0,25\%, 0,5\%, 1\%, 2\%, dan 4\%; kontrol tanpa 
ekstrak; dan fungisida propineb 0,3\%) yang diulang sebanyak empat kali. Pengujian penghambatan pertumbuhan koloni jamur $A$. solani dilakukan dengan teknik makanan beracun. Pengujian pada benih dilakukan dengan empat perlakuan dan lima ulangan yang masing-masing terdiri atas 25 benih tomat dengan menggunakan teknik perendaman. Hasil pengujian menunjukkan ekstrak kasar umbi udara binahong 2\% mampu menghambat pertumbuhan koloni $A$. solani sebesar 37,22\% dan menekan kejadian penyakit pada bibit tomat dengan penekanan mencapai $83,33 \%$.

\section{PENDAHULUAN}

Tomat (Lycopersicon esculentum) merupakan tanaman sayuran yang memiliki nilai gizi dan mempunyai banyak manfaat bagi kesehatan (Hayati dkk., 2010). Tomat juga digunakan sebagai bahan baku industri obat-obatan dan kosmetik serta bahan baku pengolahan makanan (Wijayanti \& Susila, 2013). Manfaat yang banyak pada tomat ini mengakibatkan semakin tingginya permintaan tomat (Totong dkk., 2016). Namun demikian, beberapa laporan menunjukkan terjadinya penurunan produksi tomat. Secara nasional, di tahun 2014 produksi tomat mengalami penurunan sebesar $7,74 \%$ atau menurun sebanyak 76.793 ton (Direktorat Jenderal Hortikultura, 2014). Penurunan produksi tomat tersebut tidak lepas dari serangan organisme pengganggu tanaman (OPT) antara lain serangan jamur Alternaria solani. Patogen ini merupakan penyebab penyakit bercak cokelat (early blight) pada tanaman tomat (Roy et al., 2019). Penyakit bercak cokelat menunjukkan berbagai gejala pada setiap tahap pertumbuhan tanaman tomat yaitu gejala yang timbul berupa busuk pada pangkal batang muda atau dewasa, kanker batang, bercak pada batang, bercak atau hawar daun, busuk buah, serta pada fase bibit dapat menyebabkan rebah semai (damping off) (Roy et al., 2019). A. solani mampu menyerang hampir seluruh bagian tanaman yaitu tangkai, batang, daun, ranting maupun buah tomat sehingga tidak hanya menyebabkan kerugian secara kuantitatif namun juga secara kualitatif. Buah tomat yang terserang patogen ini menjadi membusuk dan biasanya berwarna cokelat, bentuknya lebih cekung dan permukaannya lebih kasar di sekitar bagian buah sehingga hasilnya menjadi buruk dan tidak layak untuk dikonsumsi (Vakalounakis, 1991).

Pengendalian penyakit bercak cokelat umumnya dilakukan oleh petani dengan menggunakan pestisida sintetis. Namun demikian, upaya pengendalian penyakit yang lebih ramah lingkungan sudah banyak mendapat perhatian.
Penggunaan pestisida nabati atau ekstrak tanaman untuk mengendalikan penyakit pada beberapa jenis tanaman telah banyak digunakan. Ekstrak tanaman yang bersifat antimikroba telah diteliti bahkan digunakan dan memberikan hasil yang baik serta efektif dalam menekan patogen tanaman maupun mikroorganisme lain secara umum (Cowan, 1999).

Salah satu bahan alam yang dapat digunakan sebagai pestisida nabati ialah tanaman binahong (Anredera cordifolia (Ten.) Steenis). Menurut Astuti et al. (2011), tanaman binahong mengandung senyawa metabolit yaitu zat aktif saponins, alkaloids, polyphenols, flavonoid dan mono polysaccharide termasuk L-arabinose, D-galaktose, L-rhamnose. Hampir semua bagian dari tanaman binahong termasuk umbi udara, daun, serta batangnya memiliki sifat antimikroba (Miladiyah \& Prabowo, 2012). Senyawa bioaktif pada tanaman binahong ini terkandung pada daun, batang, umbi udara/aerial tuber dengan senyawa seperti saponin kandungannya jauh lebih tinggi pada umbi udara dibandingkan pada daun (Astuti et al., 2011). Di dalam pemanfaatan tanaman binahong sebagai bahan pengendalian patogen penyebab penyakit tanaman, ekstrak metanol daun binahong dilaporkan mampu menekan pertumbuhan beberapa jamur patogen seperti Rhizoctonia solani, Sarocladium sp., dan Colletotrichum acutatum pada tanaman padi dan cabai (Yulia \& Widiantini, 2018; Yulia dkk., 2019a; Yulia dkk., 2019b). Tujuan dari penelitian ini adalah untuk mengetahui tingkat keefektifan ekstrak kasar umbi udara binahong di dalam menghambat pertumbuhan koloni jamur $A$. solani dan menekan kejadian penyakit akibat $A$. solani pada bibit tomat.

\section{BAHAN DAN METODE}

Penelitian dilaksanakan di Laboratorium Fitopatologi, Departemen Hama dan Penyakit Tumbuhan, Fakultas Pertanian, Universitas Padjadjaran, Jatinangor. Penelitian menggunakan 
metode eksperimen Rancangan Acak Lengkap (RAL) dengan pengujian keefektifan ekstrak kasar umbi udara binahong terhadap penghambatan pertumbuhan koloni jamur $A$. solani. Rancangan percobaan ini terdiri lima konsentrasi ekstrak kasar umbi udara binahong yaitu $0,25 \%, 0,5 \%, 1 \%, 2 \%$, dan $4 \%$, serta perlakuan fungisida propineb $0,3 \%$ dan perlakuan tanpa ekstrak sehingga terdapat tujuh perlakuan yang diulang sebanyak empat kali untuk pengujian penghambatan pertumbuhan koloni jamur A. solani. Konsentrasi ekstrak yang digunakan di dalam pengujian penekanan kejadian penyakit pada bibit tomat merupakan konsentrasi terbaik di dalam pengujian penghambatan pertumbuhan koloni jamur $A$. solani. Data hasil percobaan dianalisis menggunakan SPSS versi 21. Analisis data dilakukan dengan ANOVA dan Uji Lanjut Duncan pada taraf nyata $5 \%$.

\section{Isolasi Patogen $A$. solani}

Jamur $A$. solani diisolasi dari buah tomat yang menunjukkan gejala. Buah tomat dicuci bersih kemudian bagian di antara yang terinfeksi dan yang sehat dipotong-potong kecil (Agrios, 2005). Potongan-potongan kecil tersebut dicelupkan selama 15 detik ke dalam larutan alkohol $70 \%$ yang kemudian direndam pada larutan sodium hipoklorit $1 \%$ selama 1 menit. Jaringan yang telah disterilisasi ini dibilas sebanyak tiga kali dengan menggunakan akuades steril dan setelah itu dikeringkan pada kertas saring steril. Kemudian, potongan tersebut diletakkan pada media tumbuh potato dextrose agar (PDA) dan diinkubasi pada suhu ruang $\left( \pm 28^{\circ} \mathrm{C}\right)$. Miselium yang tumbuh kemudian dipindahkan ke media PDA yang baru sebagai biakan murni. Jamur A. solani yang sudah ditumbuhkan pada cawan Petri ini kemudian diinkubasikan pada suhu kamar sampai digunakan di dalam percobaan.

\section{Pembuatan Ekstrak Kasar Umbi Udara Binahong}

Bahan tanaman binahong diperoleh dari daerah sekitar Soreang, Kabupaten Bandung. Pertama-tama umbi udara binahong dicuci sampai bersih dan dikeringanginkan di meja laboratorium. Untuk menghilangkan kadar air pada umbi, umbi udara binahong dikeringkan di dalam oven pada suhu $50^{\circ} \mathrm{C}$ selama $48 \mathrm{jam}$. Astuti et al. (2011) menyebutkan pengeringan bagian tanaman binahong dilakukan pada suhu $45-60^{\circ} \mathrm{C}$. Umbi udara binahong yang sudah kering lalu dihaluskan sehingga menjadi serbuk. Kemudian, serbuk umbi udara binahong sebanyak $200 \mathrm{~g}$ dimaserasi dengan menggunakan 2 liter pelarut metanol 90\% (perbandingan bahan dan pelarut 1:10 w/v) selama 3 x 24 jam. Selanjutnya dilakukan penyaringan dengan menggunakan kertas saring yang diletakkan pada corong. Hasil penyaringan ini diuapkan dengan rotary evaporator pada suhu $55-60^{\circ} \mathrm{C}$ dan penghampaan pada tekanan 580-600 mmHG (Dono dkk., 2008) sehingga diperoleh ekstrak kasar umbi udara binahong pekat.

\section{Uji Penghambatan Ekstrak Kasar Umbi Udara Binahong terhadap Pertumbuhan Koloni Jamur $A$. solani}

Pengujian penghambatan pertumbuhan koloni jamur $A$. solani adalah dengan menggunakan metode poisoned food seperti yang dilakukan oleh Kurniasih dkk. (2014). Media pertumbuhan PDA yang mengandung ekstrak kasar umbi udara binahong dengan masing-masing konsentrasi uji dipersiapkan dengan cara menimbang ekstrak kasar (masing-masing sebanyak $0,1 \mathrm{~g}, 0,2 \mathrm{~g}, 0,4 \mathrm{~g}, 0,8 \mathrm{~g}$, dan $1,6 \mathrm{~g}$ untuk masing-masing konsentrasi uji $0,25 \%, 0,5 \%, 1 \%, 2 \%$, dan $4 \%$ ) dan memasukkannya ke dalam $40 \mathrm{ml}$ PDA steril (suhu $\pm 45^{\circ} \mathrm{C}$ ) dalam botol Schott. Sebelumnya, antibiotik kloramfenikol ditambahkan sebanyak $200 \mathrm{mg} / \mathrm{l}$ ke dalam media PDA untuk mencegah pertumbuhan bakteri. Campuran PDA dan ekstrak ini kemudian dituangkan ke dalam cawan Petri sebanyak $10 \mathrm{ml}$. Perlakuan kontrol merupakan media PDA tanpa adanya pemberian ekstrak kasar umbi udara binahong serta perlakuan pembanding merupakan campuran media PDA dengan fungisida propineb $0,3 \%$.

Campuran media PDA dan ekstrak kasar umbi udara binahong maupun fungisida propineb 0,3\% dituangkan ke dalam cawan Petri steril hingga memadat yang disiapkan sebanyak empat ulangan untuk tiap perlakuannya. Cawan Petri perlakuan diinkubasikan pada suhu ruang lalu diamati pertumbuhan jamur $A$. solani pada interval waktu 24 jam sampai perlakuan kontrol telah memenuhi permukaan cawan Petri. Pengukuran diameter koloni jamur dilakukan dengan menggunakan mistar. Pengamatan juga dilakukan terhadap karakteristik makroskopis serta mikroskopis koloni atau hifa jamur. Kemungkinan terjadinya perubahan bentuk atau abnormalitas hifa karena pengaruh ekstrak kasar umbi udara binahong diamati di bawah mikroskop. 
Uji Penekanan Ekstrak Kasar Umbi Udara Binahong terhadap Kejadian Penyakit akibat $A$. solani pada Benih Tomat

Benih tomat yang digunakan diperoleh dari lahan petani tomat di Lembang, Jawa Barat yang merupakan varietas Servo. Varietas Servo merupakan varietas yang rentan terhadap jamur patogen $A$. solani. Benih diambil dari buah tomat yang menunjukkan gejala bercak cokelat dan hanya diambil bijinya dari bagian yang bergejala tersebut. Benih tomat direndam di dalam air terlebih dahulu selama dua jam. Benih yang tidak tenggelam dibuang kemudian yang berada di dasar permukaan dikeringkan di atas kertas saring. Kemudian benih direndam selama satu jam menggunakan metode Ahmed (2013) pada lima perlakuan sebagai berikut: 1) Ekstrak kasar umbi udara binahong konsentrasi 2\% yang merupakan konsentrasi paling efektif pada perlakuan sebelumnya. Ekstrak kasar umbi binahong dipersiapkan dengan cara menimbang 2 g ekstrak yang dicampur menggunakan larutan Tween-80 0,2\% yaitu 0,2 g untuk $100 \mathrm{ml}$ akuades, 2) Perlakuan fungisida, 3) Perlakuan larutan Tween-80 0,2\%, 4) Perlakuan kontrol + (benih bergejala yang direndam dengan akuades steril), serta 5) Perlakuan kontrol (benih sehat yang direndam dengan akuades steril).

Setiap perlakuan menggunakan 25 benih tomat yang ditempatkan dalam satu cawan Petri dan diulang sebanyak empat kali. Benih terlebih dahulu dikeringanginkan sebelum dipindahkan ke dalam cawan Petri yang dilapisi kertas saring lembab dan diinkubasikan selama 3 hari. Pengamatan dilakukan terhadap persentase benih yang berkecambah dan persentase kecambah benih yang terinfeksi yang masing-masing dihitung dengan rumus:

$\%$ benih berkecambah

$=\frac{\sum \text { benih yang berkecambah }}{\text { total benih }} \times 100 \%$

$\%$ kecambah benih terinfeksi

$=\frac{\sum \text { kecambah benih terinfeksi }}{\text { total benih }} \times 100 \%$

Uji Penekanan Ekstrak Kasar Umbi Udara Binahong terhadap Kejadian Penyakit akibat $A$. solani pada Bibit Tomat

Benih yang telah diberi perlakuan dan berkecambah di cawan Petri dipindahkan ke dalam baki persemaian untuk diamati pertumbuhannya hingga menjadi bibit selama 14 HST. Pengamatan dilakukan terhadap persentase benih yang tumbuh menjadi bibit, persentase kejadian penyakit pada bibit tomat, serta karakteristik pertumbuhan/kesehatan bibit dan tinggi bibit. Gejala yang mungkin timbul pada bibit tomat adalah bercak pada daun atau batang, serta rebah kecambah/damping-off akibat serangan $A$. solani. Persentase kejadian penyakit dihitung dengan rumus:

$$
\% \text { kejadian penyakit }=\frac{\sum \text { Bibit yang menunjukkan gejala penyakit }}{\text { total bibit }} \times 100 \%
$$

\section{HASIL DAN PEMBAHASAN}

Pengaruh Ekstrak Kasar Umbi Udara Binahong terhadap Penghambatan Pertumbuhan Koloni Jamur A. solani

Hasil pengujian menunjukkan bahwa ekstrak kasar umbi udara binahong mampu menghambat pertumbuhan koloni jamur $A$. solani terutama pada konsentrasi tinggi yaitu pada konsentrasi $2 \%$ dan $4 \%$ (Tabel 1). Konsentrasi ekstrak yang memberikan penghambatan tertinggi sebesar $37,22 \%$ terdapat pada perlakuan konsentrasi $2 \%$ yang diikuti penghambatan sebesar $32,33 \%$ pada perlakuan konsentrasi $4 \%$. Pertumbuhan jamur yang lebih tinggi pada penggunaan konsentrasi ekstrak yang tinggi diduga karena adanya kandungan senyawa kimia seperti gula yang dapat memacu pertumbuhan jamur. Sementara itu, pada perlakuan konsentrasi lainnya meskipun penghambatannya tergolong rendah tetapi berbeda nyata dengan perlakuan kontrol secara statistik. Ekstrak kasar umbi udara binahong dalam menghambat jamur patogen $A$. solani tergolong sedang berdasarkan kategori sifat aktivitas antijamur (antifungal activity, AFA) (Mori et al., 1995; Mori et al., 1997).

Pada perlakuan konsentrasi ekstrak kasar umbi udara binahong yang lebih rendah yaitu $0,25 \%, 0,5 \%$, dan $1 \%$ menunjukkan penghambatan yang rendah pada pertumbuhan koloni jamur $A$. solani. Hal ini diduga disebabkan terdapat senyawa bioaktif yang bersifat antimikroba dalam jumlah yang sedikit pada konsentrasi yang rendah sehingga penghambatan yang terjadi juga rendah. Peningkatan persentase penghambatan oleh ekstrak tanaman terhadap beberapa jamur pada konsentrasi yang semakin tinggi karena dinilai memiliki 
kandungan metabolit sekunder yang mampu mengendalikan jamur patogen telah banyak dilaporkan (Begum et al., 2010; Chohan et al., 2011; Ibrahim et al., 2014; Ramaiah \& Garampalli, 2015; Tapwal et al., 2011).

Tabel 1. Diameter koloni dan persentase penghambatan pertumbuhan koloni jamur A. solani dengan perlakuan ekstrak kasar umbi udara binahong pada 9 HSI

\begin{tabular}{lcc}
\hline \multicolumn{1}{c}{ Perlakuan } & $\begin{array}{c}\text { Diameter } \\
\text { koloni }(\mathrm{cm})\end{array}$ & $\begin{array}{c}\text { Penghambatan } \\
(\%)\end{array}$ \\
\hline Kontrol & $9 \mathrm{e}$ & - \\
Propineb 0,3\% & $0,68 \mathrm{a}$ & 92,44 \\
Ekstrak 0,25\% & $7,90 \mathrm{~d}$ & 12,22 \\
Ekstrak 0,5\% & $7,50 \mathrm{~d}$ & 16,66 \\
Ekstrak 1\% & $6,94 \mathrm{c}$ & 22,88 \\
Ekstrak 2\% & $5,65 \mathrm{~b}$ & 37,22 \\
Ekstrak 4\% & $6,09 \mathrm{~b}$ & 32,33 \\
\hline Keterangan: & Huruf yang sama pada satu kolom dalam tabel \\
& menunjukkan tidak berbeda nyata berdasarkan Uji \\
& Lanjut Duncan pada taraf 5\%. HSI = Hari setelah \\
& inkubasi
\end{tabular}

Beberapa hasil penelitian lainnya juga menunjukkan bahwa ekstrak tanaman binahong dengan konsentrasi $2 \%$ mampu menghambat pertumbuhan jamur patogen (Yulia \& Widiantini, 2018; Yulia dkk., 2019a). Demikian halnya dengan hasil yang dicapai pada pengujian ini, diduga kandungan senyawa bioaktif antijamur pada ekstrak kasar umbi udara binahong lebih banyak terkandung pada konsentrasi 2\% dan 4\%. Konsentrasi ekstrak yang dinilai efektif ialah konsentrasi 2\% karena selain memiliki daya hambat yang lebih tinggi dibandingkan $4 \%$ juga untuk efisiensi dan menghindari kemungkinan efek samping fitotoksik pada bahan tanaman pada penggunaan konsentrasi yang tinggi.

Pengamatan terhadap karakteristik koloni atau miselium serta hifa jamur menunjukkan adanya pengaruh ekstrak kasar umbi udara binahong terhadap bentuk dan kondisi miselium hifa jamur $A$. solani. Pertumbuhan koloni jamur yang tidak rata dan keadaan miselium yang menebal ditemukan pada perlakuan ekstrak konsentrasi tinggi (Gambar 1). Pengamatan secara mikroskopis terhadap hifa jamur menunjukkan terjadinya perubahan bentuk (abnormalitas) hifa $A$. solani pada perlakuan esktrak kasar umbi udara binahong dibandingkan hifa pada perlakuan kontrol yang bentuknya terlihat normal (Gambar 2). Pada perlakuan fungisida propineb 0,3\% hifa terlihat membengkok dan terputus. Pada konsentrasi $0,25 \%$ terdapat hifa yang mengeriting atau membengkok. Pada konsentrasi 0,5\% terdapat hifa yang membengkak (swelling). Hifa $A$. solani pada konsentrasi $1 \%$ terlihat putus dan membengkok, serta pada konsentrasi $4 \%$ hifa terlihat lisis dan mengeriting. Kerusakan paling signifikan pada konsentrasi 2\% menunjukkan beberapa perubahan seperti hifa yang menipis, hifa yang tampak kosong dengan sekat yang tidak terlihat, serta hifa yang putus. Hal ini menunjukkan bahwa ekstrak kasar umbi udara binahong yang digunakan mempunyai efek langsung terhadap jamur A. solani.

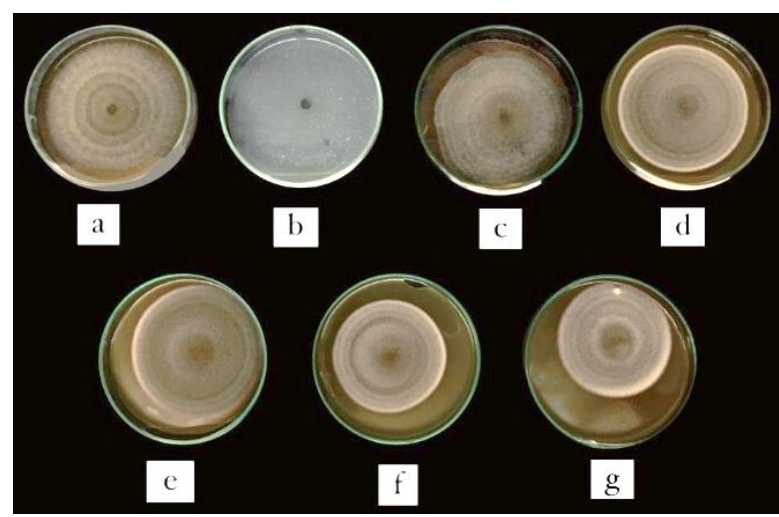

Gambar 1. Pengaruh pemberian berbagai konsentrasi ekstrak kasar umbi udara binahong terhadap pertumbuhan koloni jamur $A$. solani. (a) Kontrol. (b) Fungisida Propineb 0,3\%. (c) Ekstrak 0,25\%.

(d) Ekstrak 0,5\%. (e) Ekstrak 1\%.

(f) Ekstrak 2\%. (g) Ekstrak 4\%.

Binahong memiliki senyawa terpenoid yang dapat menghambat dan mengganggu proses terbentuknya membran dan dinding sel jamur. Senyawa ini mampu menghambat pertumbuhan dan perkembangan jamur, baik melalui membran sitoplasma maupun mengganggu pertumbuhan dan perkembangan spora jamur (Darsana dkk., 2012; Lutfiyanti dkk., 2012; Natta et al., 2008). Hal ini yang menyebabkan dinding sel jamur yang telah diberi perlakuan esktrak mengalami penipisan dinding sel serta perubahan hifa yang tidak normal seperti mengeriting, membengkok dan membengkak (swelling) (Gambar 2).

Beberapa penelitian menunjukkan bahwa tanaman binahong memiliki senyawa bioaktif seperti flavonoid, saponin, triterpenoid, komarin 
dan asam fenolat yang bersifat antifungi dan dapat merusak hifa jamur (Astuti et al., 2011; Djamil et al., 2012). Tanaman binahong memiliki kandungan senyawa saponin yang lebih besar dari pada senyawa lainnya, terutama pada umbi yang berperan sebagai antimikroba. Saponin termasuk senyawa glikon (gula) dan senyawa aglikon, adapun senyawa aglikon adalah termasuk golongan steroid dan terpenoid (Manoi, 2009).

Senyawa flavonoid juga mempunyai peranan yang penting bagi ketahanan tanaman terhadap bakteri dan jamur patogen. Flavonoid dapat meningkatkan aktivitas auksin (IAA) sehingga mampu memperkuat struktur jaringan yang ada pada tanaman dengan penutupan sistem vaskular sehingga mencegah infeksi patogen serta pembentukan kalus (Beckman, 2000).
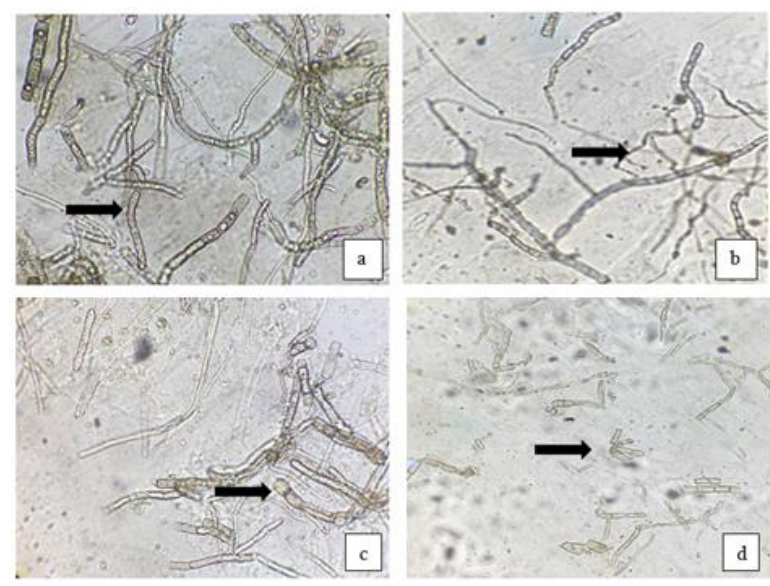

Gambar 2. Morfologi hifa secara mikroskopis hasil uji ekstrak kasar umbi udara binahong terhadap jamur A. solani. (a) Hifa normal pada perlakuan kontrol. (b) Hifa mengeriting atau membengkok. (c) Hifa yang membengkak (swelling). (d) Hifa yang putus dan menipis.

\section{Pengaruh Ekstrak Kasar Umbi Udara Binahong terhadap Penekanan Infeksi $A$. solani yang Terbawa Benih pada Kecambah Benih Tomat}

Hasil pengamatan terhadap benih yang berkecambah menunjukkan bahwa perendaman benih dengan esktrak kasar umbi binahong 2\% mampu meningkatkan benih tomat yang berkecambah (100\%) bahkan dibandingkan dengan perlakuan kontrol negatif (benih yang sehat) yang hanya mencapai $90 \%$ (Tabel 2). Sementara itu, untuk perlakuan fungisida propineb $0,3 \%$, benih yang berkecambah lebih rendah dibandingkan dengan perlakuan lainnya yaitu sebesar 51\%. Hal ini diduga karena terjadi fitotoksik yaitu konsentrasi propineb $0,3 \%$ yang digunakan untuk perlakuan benih pada percobaan ini tergolong tinggi sehingga menurunkan daya kecambah. Pengamatan dilakukan pada 3 HSI ketika pertama kali gejala infeksi maupun kolonisasi jamur $A$. solani terjadi pada kecambah benih tomat. Persentase penekanan kecambah benih tomat terinfeksi pada perlakuan fungisida propineb $0,3 \%$ yaitu sebesar $100 \%$. Sementara itu, persentase penekanan kecambah benih terinfeksi pada perlakuan ekstrak kasar umbi binahong $2 \%$ tergolong tinggi yaitu sebesar 66,66\%.

Gejala infeksi patogen $A$. solani pada kecambah benih tomat ini adalah terjadinya perubahan warna (diskolorisasi) dengan kecambah benih menjadi berwarna abu-abu, cokelat atau kehitaman karena busuk atau kolonisasi jamur, maupun terdapatnya bercak nekrotik pada radikula. Kejadian infeksi yang cukup berat dimana benih atau kecambah benih yang menunjukkan gejala infeksi penyakit terlihat busuk berwarna abu-abu atau hitam terutama terjadi pada perlakuan Tween80 0,2\%. Kejadian penyakit pada perlakuan Tween80 0,2\% bahkan lebih tinggi daripada perlakuan kontrol positif.

Tabel 2. Persentase benih berkecambah dan kecambah benih terinfeksi $A$. solani pada pengujian ekstrak kasar umbi binahong pada 3 HSI

\begin{tabular}{lccc}
\hline Perlakuan & $\begin{array}{c}\text { Benih yang } \\
\text { berkecambah (\%) }\end{array}$ & $\begin{array}{c}\text { Kecambah benih } \\
\text { yang terinfeksi (\%) }\end{array}$ & $\begin{array}{c}\text { Penekanan benih } \\
\text { yang terinfeksi (\%) }\end{array}$ \\
\hline Kontrol - & 90 & $0 \mathrm{a}$ & - \\
Kontrol + & 99 & $27 \mathrm{c}$ & - \\
Tween-80 0,2\% & 85 & $58 \mathrm{~d}$ & Tm \\
Ekstrak 2\% & 100 & $9 \mathrm{~b}$ & 66,66 \\
Propineb 0,3\% & 51 & $0 \mathrm{a}$ & 100 \\
\hline
\end{tabular}

Keterangan: Huruf yang sama pada satu kolom dalam tabel menunjukkan tidak berbeda nyata berdasarkan Uji Lanjut Duncan pada taraf 5\%. Tm = Tidak Menghambat. HSI = Hari setelah inkubasi. Kontrol - = benih sehat yang direndam dengan akuades steril. Kontrol $+=$ benih bergejala yang direndam dengan akuades steril. 
Kejadian penyakit yang tinggi pada perlakuan Tween-80 0,2\% ini diduga penggunaan larutan Tween-80 0,2\% mempermudah penempelan inokulum jamur $A$. solani pada saat perendaman benih karena Tween-80 0,2\% dapat meratakan setiap sisi atau bagian benih sehingga semua bagian menjadi terinfeksi. Benih tomat yang diberi perlakuan Tween-80 0,2\% dan perlakuan kontrol positif umumnya tampak terkolonisasi oleh miselia jamur $A$. solani yang kemudian dapat menyebabkan kecambah menjadi terinfeksi pada perkembangan selanjutnya dengan menunjukkan gejala bercak nekrotik berwarna cokelat.

\section{Pengaruh Ekstrak Kasar Umbi Udara Binahong terhadap Penekanan Kejadian Penyakit akibat $A$. solani pada Bibit Tanaman Tomat}

Benih yang telah berkecambah dipindahkan ke dalam baki untuk melihat pertumbuhan bibitnya. Hasil pengamatan pada 7 HST menunjukkan bahwa jumlah benih yang tumbuh menjadi bibit pada perlakuan fungisida propineb $0,3 \%$ dan ekstrak $2 \%$ tidak berbeda nyata dimana seluruh benih berhasil tumbuh. Sementara itu, perlakuan kontrol positif yaitu benih yang sakit dengan perlakuan akuades dan perlakuan Tween-80 0,2\% berbeda nyata dengan perlakuan ekstrak 2\% (Tabel 3). Pada perlakuan Tween-80 0,2\% benih yang tumbuh hanya sedikit. Hal ini diduga karena perendaman benih menggunakan larutan Tween-80 0,2\% mempermudah inokulum jamur $A$. solani menempel pada seluruh bagian benih atau kecambah benih. Hal tersebut mengakibatkan seluruh bagian benih menjadi lebih terinfeksi sehingga kejadian infeksi sangat tinggi dan benih tidak mampu tumbuh menjadi bibit. Menurut Adhikari et al. (2017) jamur patogen $A$. solani yang menginfeksi benih dapat menyebabkan benih mengalami kerusakan sel-sel endosperm dan mengakibatkan embrio mengalami plasmolisis. Plasmolisis menandakan adanya kebocoran metabolit dari dalam benih sehingga terjadi penurunan viabilitas benih.

Perlakuan benih dengan ekstrak kasar umbi binahong pada konsentrasi $2 \%$ tidak berbeda nyata dengan perlakuan fungisida propineb $0,3 \%$ dan kontrol negatif yaitu dengan penekanan sebesar $100 \%$ (Tabel 3). Sementara itu, pada perlakuan Tween-80 0,2\% penekanan kejadian penyakit sangat rendah hanya sebesar $36,36 \%$. Gejala yang dialami oleh bibit tomat diantaranya adalah bercak cokelat di sekitar daun dan batang serta rebah semai (damping-off) akibat busuk pada pangkal batangnya (Gambar 3).

Tabel 3. Persentase benih yang tumbuh menjadi bibit dan persentase kejadian penyakit pada bibit tomat dengan perlakuan ekstrak kasar umbi binahong pada 7 HST

\begin{tabular}{lccc}
\hline \multicolumn{1}{c}{ Perlakuan } & $\begin{array}{c}\text { Benih yang tumbuh } \\
\text { menjadi bibit (\%) }\end{array}$ & Kejadian penyakit (\%) & $\begin{array}{c}\text { Penekanan kejadian } \\
\text { penyakit (\%) }\end{array}$ \\
\hline Kontrol - & $100 \mathrm{c}$ & $0 \mathrm{a}$ & - \\
Kontrol + & $74 \mathrm{~b}$ & $22 \mathrm{c}$ & - \\
Tween-80 0,2\% & $57 \mathrm{a}$ & $14 \mathrm{~b}$ & 36,36 \\
Ekstrak 2\% & $100 \mathrm{c}$ & $0 \mathrm{a}$ & 100 \\
Propineb 0,3\% & $100 \mathrm{c}$ & $0 \mathrm{a}$ & 100 \\
\hline Keterangan: Huruf yang sama pada satu kolom dalam tabel menunjukkan tidak berbeda nyata berdasarkan Uji Lanjut Duncan pada \\
taraf 5\%. HST = Hari setelah tanam. Kontrol - = benih sehat yang direndam dengan akuades steril. Kontrol + = benih \\
bergejala yang direndam dengan akuades steril.
\end{tabular}

Gejala penyakit bercak cokelat dan dampingoff sudah terlihat jelas pada pengamatan 7 HST meskipun tidak terjadi secara keseluruhan. Bercak yang ditimbulkan pada daun berupa bercak-bercak kecil berwarna cokelat hingga hitam (lesi) dan berbentuk konsentris (Gambar 3). Gejala infeksi $A$. solani pada bibit tomat ini sama dengan yang dilaporkan oleh Sanoubar \& Barbanti (2017). Kejadian damping-off yang parah terjadi pada perlakuan Tween-80 0,2\% dan kontrol positif. Hal ini diduga karena busuk pada bakal akar dan terjadi bercak cokelat pada batang atau busuk pada pangkal batangnya mengakibatkan bibit rebah/tidak tegak dan tampak tidak sehat.

Benih yang terinfeksi menyebabkan bakal akar mengalami busuk hitam dan terjadi bercak cokelat atau busuk pada batang yang berakibat tanaman tidak mampu berdiri tegak atau normal. Daun muda dan batang yang masih lunak sangat rentan terserang jamur akibatnya tanaman mengalami damping-off. 
Bibit yang telah mengalami damping-off sebagian besar sangat jarang tumbuh normal kembali karena akar, batang dan daun yang telah rusak akibat serangan patogen umumnya tidak mampu tumbuh menjadi tanaman dewasa (Walker, 1952 dalam Roy et al., 2019). Pengamatan 7 HST juga menunjukkan bahwa perlakuan Tween-80 0,2\% dan kontrol positif menyebabkan pertumbuhan bibit menjadi lebih kecil atau kerdil dibandingkan perlakuan ekstrak umbi binahong $2 \%$, propineb 0,3\% dan kontrol negatif.

Hasil pengamatan terakhir (14 HST) secara statistik menunjukkan bahwa perendaman benih dengan ekstrak kasar umbi binahong 2\% tidak berbeda nyata dengan perlakuan fungisida propineb 0,3\% dalam menekan kejadian penyakit pada bibit tomat (Tabel 4). Penekanan kejadian penyakit pada bibit tomat pada perlakuan ekstrak kasar umbi binahong 2\% mencapai $83,33 \%$ yang merupakan penekanan tertinggi kedua setelah perlakuan fungisida propineb $0,3 \%$ dan kontrol negatif. Pengamatan 14 HST juga menunjukkan hasil bahwa perlakuan Tween-80 0,2\% memberikan penekanan gejala bercak cokelat yang rendah yaitu $30,55 \%$.
Tabel 4. Persentase kejadian penyakit pada bibit tomat pada pengujian ekstrak kasar umbi binahong pada 14 HST

\begin{tabular}{lcc}
\hline Perlakuan & $\begin{array}{c}\text { Kejadian } \\
\text { penyakit (\%) }\end{array}$ & $\begin{array}{c}\text { Penekanan } \\
(\%)\end{array}$ \\
\hline Kontrol - & $0 \mathrm{a}$ & 100 \\
Kontrol + & $36 \mathrm{c}$ & - \\
Tween-80 0,2\% & $25 \mathrm{~b}$ & 30,55 \\
Ekstrak 2\% & $6 \mathrm{a}$ & 83,33 \\
Propineb 0,3\% & $0 \mathrm{a}$ & 100 \\
\hline Keterangan: Huruf yang sama pada satu kolom dalam tabel \\
menunjukkan tidak berbeda nyata berdasarkan Uji \\
Lanjut Duncan pada taraf 5\%. HST = Hari setelah \\
tanam. Kontrol - = benih sehat yang direndam \\
dengan akuades steril. Kontrol + = benih bergejala \\
yang direndam dengan akuades steril
\end{tabular}

Banyaknya bibit yang mengalami dampingoff disebabkan oleh kejadian busuk pada akar atau busuk pada pangkal batang. Adhikari et al. (2017) menyebutkan bahwa aktivitas senyawa alternariol, altertoksin dan altersolanol yang diproduksi oleh $A$. solani bersifat toksik atau merugikan yang mampu mengakibatkan busuk pada pangkal batang sehingga bibit tomat tidak mampu tumbuh normal dan lamakelamaan dapat menyebabkan kejadian damping-off.
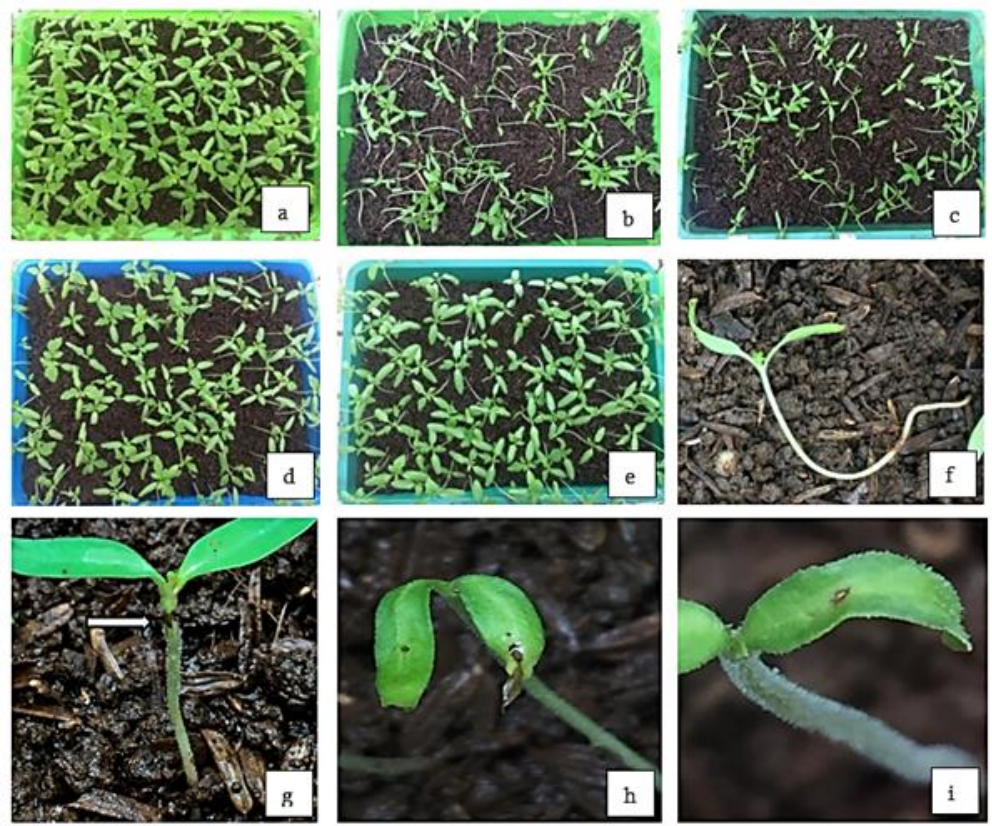

Gambar 3. Kondisi pertumbuhan serta gejala yang muncul akibat infeksi $A$. solani pada perlakuan benih tomat dengan ekstrak kasar umbi binahong pada 14 HST. (a) Perlakuan kontrol -. (b) Perlakuan kontrol +. (c) Perlakuan Tween-80 0,2\%. (d) Perlakuan Ekstrak 2\%. (e) Perlakuan Propineb $0,3 \%$. (f) Bibit yang mengalami damping-off. (g) Bibit yang memiliki bercak cokelat di batang. $(h, i)$ Bibit yang memiliki bercak cokelat pada daun. 
Infeksi jamur $A$. solani mengakibatkan terhambatnya pertumbuhan bibit tomat (Tabel 5; Gambar 4). Infeksi yang berat pada benih untuk perlakuan Tween-80 0,2\% mengakibatkan rata-rata tinggi bibit tomat hanya $3,95 \mathrm{~cm}$, sedangkan pada perlakuan fungisida propineb $0,3 \%$ menghasilkan rata-rata tinggi bibit tomat tertinggi sebesar $6,23 \mathrm{~cm}$. Pada perlakuan ekstrak kasar umbi binahong 2\% rata-rata tinggi bibit tomat mencapai $5,53 \mathrm{~cm}$, nilai ini lebih tinggi dan berbeda nyata dengan kontrol positif yaitu sebesar $4,50 \mathrm{~cm}$.

Tabel 5. Pengaruh perlakuan benih tomat dengan ekstrak kasar umbi udara binahong terhadap pertumbuhan bibit tomat

\begin{tabular}{lc}
\hline \multicolumn{1}{c}{ Perlakuan } & Tinggi bibit $(\mathrm{cm})$ \\
\hline Kontrol - & $5,96 \mathrm{~d}$ \\
Kontrol + & $4,50 \mathrm{~b}$ \\
Tween-80 0,2\% & $3,95 \mathrm{a}$ \\
Ekstrak 2\% & $5,53 \mathrm{c}$ \\
Propineb 0,3\% & $6,23 \mathrm{~d}$ \\
\hline Keterangan: Huruf yang sama pada satu kolom dalam tabel \\
menunjukkan tidak berbeda nyata berdasarkan Uji \\
Lanjut Duncan pada taraf 5\%. HST = Hari setelah \\
tanam. Kontrol - = benih sehat yang direndam \\
dengan akuades steril. Kontrol + = benih bergejala \\
yang direndam dengan akuades steril
\end{tabular}

Pada pengamatan terakhir perlakuan ekstrak umbi binahong $2 \%$ tidak terlalu tinggi di antara perlakuan lainnya tetapi kondisi daunnya memiliki warna yang hijau dan lebar (Gambar 4). Hal ini terjadi karena binahong mengandung glukosa yang berguna bagi pembentukan hijau daun pada tanaman (Rachmawati, 2008).

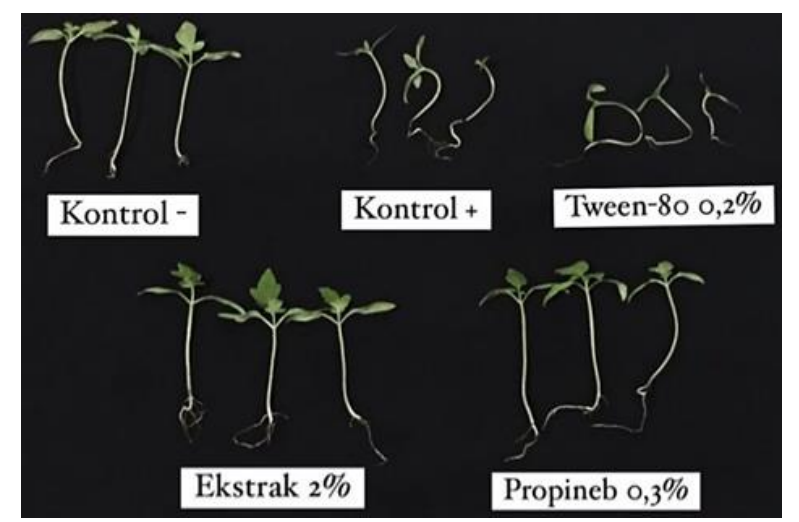

Gambar 4. Pertumbuhan atau tinggi bibit tomat pada semua perlakuan pada pengujian ekstrak kasar umbi udara binahong.
Penelitian ini juga membuktikan bahwa perlakuan benih tomat dengan ekstrak kasar umbi binahong mampu memberikan penekanan terhadap kejadian infeksi pada benih, serta mampu menekan kejadian penyakit pada bibit tomat yaitu kejadian rebah semai/damping-off dan bercak cokelat pada bibit tomat. Menurut Kemmitt (2002) pada fase bibit tomat terjadi kemunculan bercak cokelat pada daun dan batang akibat serangan jamur patogen $A$. solani yang mampu menyebabkan kerusakan pada bibit tomat sehingga terjadi penurunan vigor dan dapat menyebabkan kematian sebelum tanaman dewasa.

Perlakuan benih tomat dengan perendaman ekstrak umbi udara binahong juga dapat memengaruhi karakteristik pertumbuhan bibit tomat. Beberapa penelitian sebelumnya telah melaporkan bahwa kandungan senyawa bioaktif di dalam tanaman binahong, tidak hanya memiliki sifat antimikroba tetapi juga memiliki sifat lainnya seperti antioksidan (Astuti et al., 2011; Djamil et al., 2012). Senyawa bioaktif tersbut diduga dapat memengaruhi kesehatan dan ketahanan sel pada tanaman sehingga dapat meningkatkan pertumbuhan tanaman.

\section{SIMPULAN}

Berdasarkan hasil pengujian yang telah dilakukan dapat disimpulkan bahwa ekstrak kasar umbi binahong pada konsentrasi 2\% mampu menghambat pertumbuhan koloni jamur $A$. solani dengan tingkat penghambatan yang sedang yaitu sebesar 37,22\%. Ekstrak kasar umbi udara binahong mengakibatkan kerusakan dan abnormalitas hifa jamur A. solani. Ekstrak kasar umbi udara binahong dengan konsentrasi 2\% dapat menekan kejadian infeksi benih tomat sebesar $66,66 \%$ serta menekan kejadian penyakit pada bibit tomat mencapai $83,33 \%$.

\section{DAFTAR PUSTAKA}

Adhikari, P, Y Oh, and DR Panthee. 2017. Current status of early blight resistence in tomato: An update. International Journal of Molecular Sciences. 18(10): 2-22.

Agrios, GN. 2005. Plant Pathology. $5^{\text {th }}$ Ed. Academic Press. San Diego.

Ahmed, M, M Hossain, K Hassan, and CK Dash. 2013. Efficacy of different plant extract on reducing seed borne infection and increasing 
germination of collected rice seed sample. Univers. J. Plant Sci. 1(3): 66-73.

Astuti, SM, M Sakinah, R Andayani, and A Risch. 2011. Determination of saponin compound from Anredera cordifolia (Ten) Steenis plant (binahong) to potential treatment for several diseases. Journal of Agriculture Science. 3(4): $224-232$.

Beckman, CH. 2000. Phenolic-storing cells: Keys to programmed cell death and periderm formation in wilt disease resistance and in general defence responses in plants? Physiol. Mol. Plant Pathol. 57: 101-110

Begum, MF, MF Mahaland, and MdS Alam. 2010. Inhibition of spore germination and mycelial growth of three fruit rot pathogens using some chemical fungicides and botanical extracts. Journal of Life Earth Sciences. 1 (5): 23-27.

Chohan, S, R Atiq, MA Mehmood, S Naz, B Siddique, and G Yasmin. 2011. Efficacy of few plant extracts against Fusarium oxysporum $\mathrm{f}$. sp. gladioli, the cause of corm rot of gladiolus. Journal of Medicinal Plants Research. 5 (16): 3887-3890.

Cowan, M. 1999. Plant Product as antimicrobial agents. Journal of Clinical Microbiology Reviews. 12(4): 564-582.

Darsana, IGO, INK Besung, dan H Mahatmi. 2012. Potensi daun binahong (Anredera cordifolia (Tenore) Steenis) dalam menghambat pertumbuhan bakteri $E$. coli secara in vitro. Indones Medicus Veterinus. 1: 337-351.

Djamil, R., PS Wahyudi, S Wahono, and M Hanafi. 2012. Antioxidant activity of flavonoid fron Anredera cordifolia (Ten) Steenis leaves. International Research Journal of Pharmacy. 3(9): 241-243.

Direktorat Jenderal Hortikultura. 2014. Statistik Produksi Hortikultura. Kementerian Pertanian. Tersedia online pada http://hortikultura.pertanian.go.id/wpcontent/uploads/2016/02/Statistik-Produksi2014.pdf. Diakses 29 Oktober 2020.

Dono, D, S Hidayat, C Nasahi, dan E Anggraini. 2008. Pengaruh ekstrak biji Barringtonia asiatica L. (Kurz) (Lecythidaceae) terhadap mortalitas larva dan fekunditas Crocidolomia pavonana F. (Lepidoptera: Pyralidae). Jurnal Agrikultura. 19(1): 5-14.

Hayati, M, E Hayati, dan K Narossa. 2010. Pengaruh pupuk kompos lamtorogung (Leucaena leucocephala) dan jarak tanam terhadap pertumbuhan dan hasil tanaman tomat (Lycopersicum esculentum Mill.). Jurnal Agrista. 14(1): 8-13.

Kemmitt, G. 2002. Early Blight of Potato and Tomato. Available online at https://www.apsnet.org/edcenter/disandpath/ fungalasco/pdlessons/Pages/PotatoTomatoEst onian.aspx. Accessed 29 October 2020.

Kurniasih, R, S Djauhari, A Muhibuddin, dan EP Utomo. 2014. Pengaruh sitronelal serai wangi (Cymbopogon winterianus Linn) terhadap penekanan serangan Colletotrichum sp. pada tanaman bawang daun (Allium fistulosum L.). Jurnal HPT. 2(4):11-21.

Lutfiyanti, R, WF Ma'aruf, dan EN Dewi. 2012. Aktivitas antijamur senyawa bioaktif ekstrak Gelidium latifolium terhadap Candida albicans. Jurnal Pengolahan dan Bioteknologi Hasil Perikanan. 1(1) : 1-8.

Ibrahim, M, K Shehu, IY Tafinta, UA Imam, and YI Hassana. 2014. Efficacy of some plant extracts on growth and germination of Rhizopus stolonifer and Fusarium oxysporum isolated from rotten irish potato tubers. Annals of Biological Sciences. 2(3): 63-67.

Natta, L, K Orapin, N Krittika, dan B Pantip. 2008. Essensial oil from zingiberaceae for anti foodborne bacteria. International Food Research Journal. 15(3): 337-346.

Manoi, F. 2009. Binahong (Anredera cordifolia) sebagai obat. Warta Penelitian dan Pengembangan Tanaman Industri. 15(1): 3-5.

Miladiyah, I, and BR Prabowo. 2012. Ethanolic extract of Anredera cordifolia (Ten.) Steenis leaves improved wound healing in guinea pigs. Universa Medicina. 31(1): 4-11.

Mori, M, M Aoyama, S Doi, A Kanetoshi, and T Hayashi. 1995. Antifungal activity of bark extracts of conifers. Holz als Roh-und Werkstoff. 53(2): 81-82.

Mori, M, M Aoyama, S Doi, A.Kanetoshi, and T Hayashi. 1997. Antifungal activity of bark extract of deciduous trees. Holz als Roh-und Werkstoff. 55(2-4): 130-132.

Vakalounakis, D. 1991. Control of early blight of greenhourse tomato, caused by Alternaria solani, by inhibiting sporulasi with ultraviolet-absorbing vinyl film. Plant Disease. 75: 795-797. 
Rachmawati, S. 2008. Study Macroscopic, dan Skrining Fitokimia Daun Anredera cordifolia (Ten) Steenis. [Tesis]. Airlangga University. Indonesia.

Ramaiah, AK, and RKH Garampalli. 2015. In vitro antifungal activity of some plant extracts against Fusarium oxysporum f. sp. lycopersici. Asian Journal of Plant Science and Research. 5 (1): 22-27.

Roy, KC, N Akter, MKI Sarkar, MPk Uddin, N Begum, EA Zenat, and MAA Jahan. 2019. Control of early blight of tomato caused by Alternaria solani and screening of tomato varieties against the pathogen. The Open Microbiology Journal. 13: 41-50.

Sanoubar, R, and L Barbanti. 2017. Fungal diseases on tomato plant under greenhouse condition. European Journal of Biological Research. 7(4): 299-308.

Tapwal, A, Nisha, S Garg, N Gautam, and R Kumar. 2011. In vitro antifungal potency of plant extracts against five phytopathogens. Brazilian Archives of Biology and Technology. 54(6): 1093-1096.

Totong, O, A Hadid, dan H Mas'ud. 2016. Pertumbuhan dan hasil tanaman tomat
(Lycopersicum esculentum mill) pada berbagai media tumbuh dengan interval penyiraman air kelapa yang berbeda. Jurnal Agrotekbis. 4(6): 693-701.

Wijayanti, E, dan AD Susila. 2013. Pertumbuhan dan produksi dua varietas tomat (Lycopersicon esculentum Mill.) secara hidroponik dengan beberapa komposisi media tanam. Bul. Agrohorti. 1(1): 104-112.

Yulia, E, dan F Widiantini. 2018. Ekstrak tanaman binahong sebagai pengendali penyakit hawar pada pelepah daun padi. Jurnal Fitopatologi Indonesia. 14(4): 138-144.

Yulia, E, HS Muhadam, F Widiantini, dan W Kurniawan. 2019a. Perlakuan benih dengan ekstrak Anredera cordifolia untuk menekan kejadian penyakit hawar bibit pada benih cabai terinfeksi Colletotrichum acutatum. Jurnal Agrikultura. 30 (2): 75-82.

Yulia, E, SRD Syafira, F Widiantini, dan W Kurniawan. 2019b. Uji penghambatan pertumbuhan jamur Sarocladium oryzae, penyebab penyakit busuk pelepah padi, dengan ekstrak metanol daun binahong. Jurnal Cropsaver. 2(1): 15-21. 